\title{
Model of Intellectual Capital Management at Universities, Based on Transactional Approach
}

\author{
Kramin T. V. ${ }^{1}$, Fatkhiev A. M. ${ }^{2}$, Timiryasova A. V. ${ }^{1}$ \& Kochetkova N. V. ${ }^{1}$ \\ ${ }^{1}$ Institute of Economics, Management and Law, Kazan, Russian Federation \\ ${ }^{2}$ Kazan Federal University, Institute of Management, Economics and Finance, Kazan, Russia \\ Correspondence: Kramin T. V., Institute of Economics, Management and Law, 420111 Kazan, Russian \\ Federation.
}

Received: March 10, 2015 Accepted: March 31, 2015 Online Published: April 30, 2015

doi:10.5539/ass.v11n11p148

URL: http://dx.doi.org/10.5539/ass.v11n11p148

\begin{abstract}
The article considers the hierarchical structure of intellectual capital, highlights the main types of transaction costs, typical for the intellectual capital of non-state universities, provides a model of intellectual capital management based on the transaction costs reduction.
\end{abstract}

Keywords: intellectual capital, transaction costs, risks

\section{Introduction}

In today's post-industrial society the attention of public organizations and scientists in Russia is focused on the problem of the national innovation system development (Dezhina \& Saltykov, 2005; Gokhberg, 2004; Gokhberg \& Kuznetsova, 2011).

The high level of intellectual capital profitability compared to physical capital in the formation of post-industrial economy and the development of market relations has significantly transformed the conditions of the higher education system functioning (Кочеткова \& Крамин, 2011; Кочеткова, 2011).

The field of educational services is unique because the main activity of educational institutions is knowledge transfer, allowing to increase the value of intellectual capital (Note 1) of not only enterprises and other industries (Naidoo, 2003), but the country as a whole (Note 2). The main "tool" of the activities of organizations, working in the field of educational services, is intellectual capital. In the absence of consensus about the content and structure of the intellectual capital of educational institutions (Fazlagic, 2005; Meek, 2000; Nerdrum \& Erikson, 2001; Ramírez, Tejada, \& Baidez, 2013), it is necessary to create a structure that will allow to link the processes of intellectual capital development management and to organize the internal structure in such a way as to stimulate and support the processes of self-organization of education.

The analysis of scientific works of the leading Russian and foreign scientists, dedicated to the intellectual capital management (например, Vagnoni, Guthrie, \& Steane, 2005), allows to conclude that no unified theoretical approach to this concept has been developed in the economic literature so far.

In the present work, the intellectual capital is defined as a non-financial resource, which gives a competitive advantage and can add value to the organization.

The comparative analysis of the intellectual capital characteristics by existing approaches, as well as the conducted research of the value chain, allowed to identify three successive interconnected large elements that define the hierarchical structure of value creation, determining possible ways of optimizing the end-to-end business processes (Figure 1).

Assets of I level include the human capital. The functioning of any organization starts with the formation of this asset. Speaking about the field of educational services, assets of level I include: leadership, or management personnel, teaching staff, teaching and support staff and other employees, to a certain extent ensuring the educational process and research activities. 


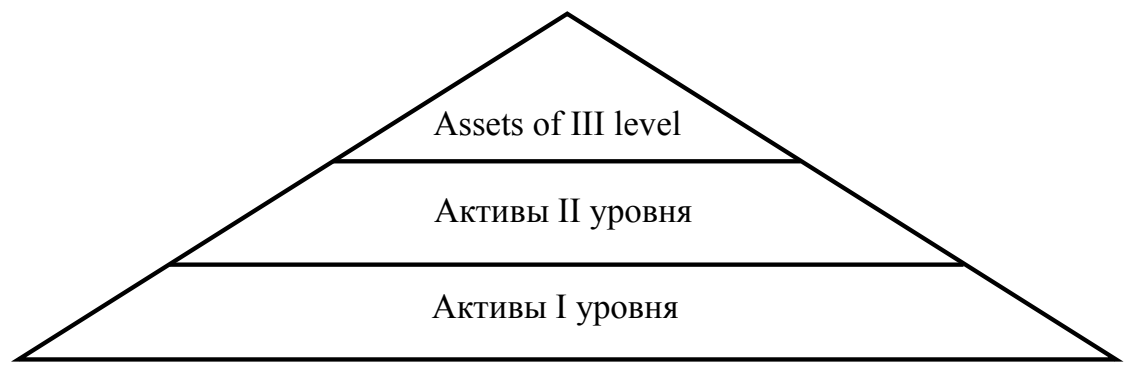

Figure 1. Intellectual capital structure

Assets of level II is what remains of the company, when people leave their jobs. The formation of this asset begins with the creation of the original name and logo, which are a tool to protect the company's assets. After studying the market, which the company is planning to enter, they generate ideas, develop scientific-technical inventions, which lead to the formation of corporate culture, managerial processes, informational technologies, production technologies, computer and administrative systems, network interaction systems. From the point of view of the university's main activities and the classical marketing theory, the product is the educational program. The next component of the II level assets is the organizational and administrative structure of the university, which affects such components as brand, reputation, image, which increase the value of intellectual capital.

The III level assets include customer capital, technologies for attracting, retaining and expanding the client network. At this level transformation of the I and II levels assets into financial assets takes place. Since the main income of the institutions of educational services is formed of revenues from tuition fees, the assets of this level are the consumers of educational services: students, businesses and organizations that hire graduates; other educational institutions as consumers of textbooks, manuals and training of their employees; the staff of the educational institution and employees of different industries; parents and students choosing the educational institution, depending on a number of conditions and parameters; the company sending their employees for training; the government ordering a specific training program for managers; other contact audiences, directly or indirectly interested in the activities of the university.

The specificity of the assets of the educational services institutions is high, therefore, according to the Williamson theory (Уильямсон, 1996) transactional costs of these assets managing are high (Воронцова, Крамин, \& Крамин, 2011; Крамин, 2007a, 2007b).

Transactional costs of educational services institutions include:

1) costs associated with the uncertainty of the workforce skills. The modern methods estimate the company's value taking into account the level of preparedness and capacity of staff, so the volume levels of education have a direct impact on the company valuation;

2) the cost of opportunistic behavior. The employees, educational institutions, and students may manifest opportunistic behavior;

3) the cost of measurement. The costs of measurement are associated with information asymmetry, which cannot be completely eliminated. For example, it is not possible to measure the quality of an employee, the only evidence of their qualification is the diploma and the characteristics of the previous places of work; to assess the quality of teaching they can be judged either by the student progress (which is estimated by the lecturer), or the colleagues (which is also a subjective assessment);

4) costs of information search. These costs consist of the time and resources necessary to conduct the search, as well as of the losses associated with the incompleteness and imperfection of the acquired information. As the change in demographic, political, economic and other information becomes faster, the content, volume and objectives of education drastically changes, which demands the constant analysis of information referring not only to the labor market demands, but also the direction of state regulation as a whole. For example, alongside with demographic situation, the number of students is influenced by the level of training of students, and, therefore, universities need to focus on the level of their education. Acceptance to college students with a low level of training will negatively affect further learning.

The factors affecting the number of students of non-state universities include the standard of living of the population, which determines what price people are willing to pay for the provision of educational services; 
5) the costs of exit from the market. These costs include the costs enterprises and organizations bear in order to strengthen their position in the market. Marketing of educational services the universities not only have to possess a well-defined educational program, because in addition to providing educational services they provide other types of goods and services that perform auxiliary functions: hospitality services and tourism (for example, provision of hostels); conference tourism (for example, services provided during conferences and other events); goods accompanying and supporting the process of learning (e.g., textbooks written by the professors; monographs, collections of articles, magazines and other periodicals);

6) the costs of specification and protection of property rights. This category includes the costs of time and resources needed to restore the violated rights, as well as losses from their improper specifications and unreliable protection;

7) the costs of negotiating and concluding contracts. This type of costs is due to the poorly signed or poorly structured contracts. The main tool to avoid these costs is to sign standard contracts. To compose an appropriate contract, one should know the functioning legislation. The provision of paid educational services is a typical source of extra-budgetary revenues, therefore, they occupy a significant place in the system of income-generating activities, among selling goods, executin of works and rendering of services.

The costs of negotiating and concluding contracts also include costs associated with signing contracts with potential employers.

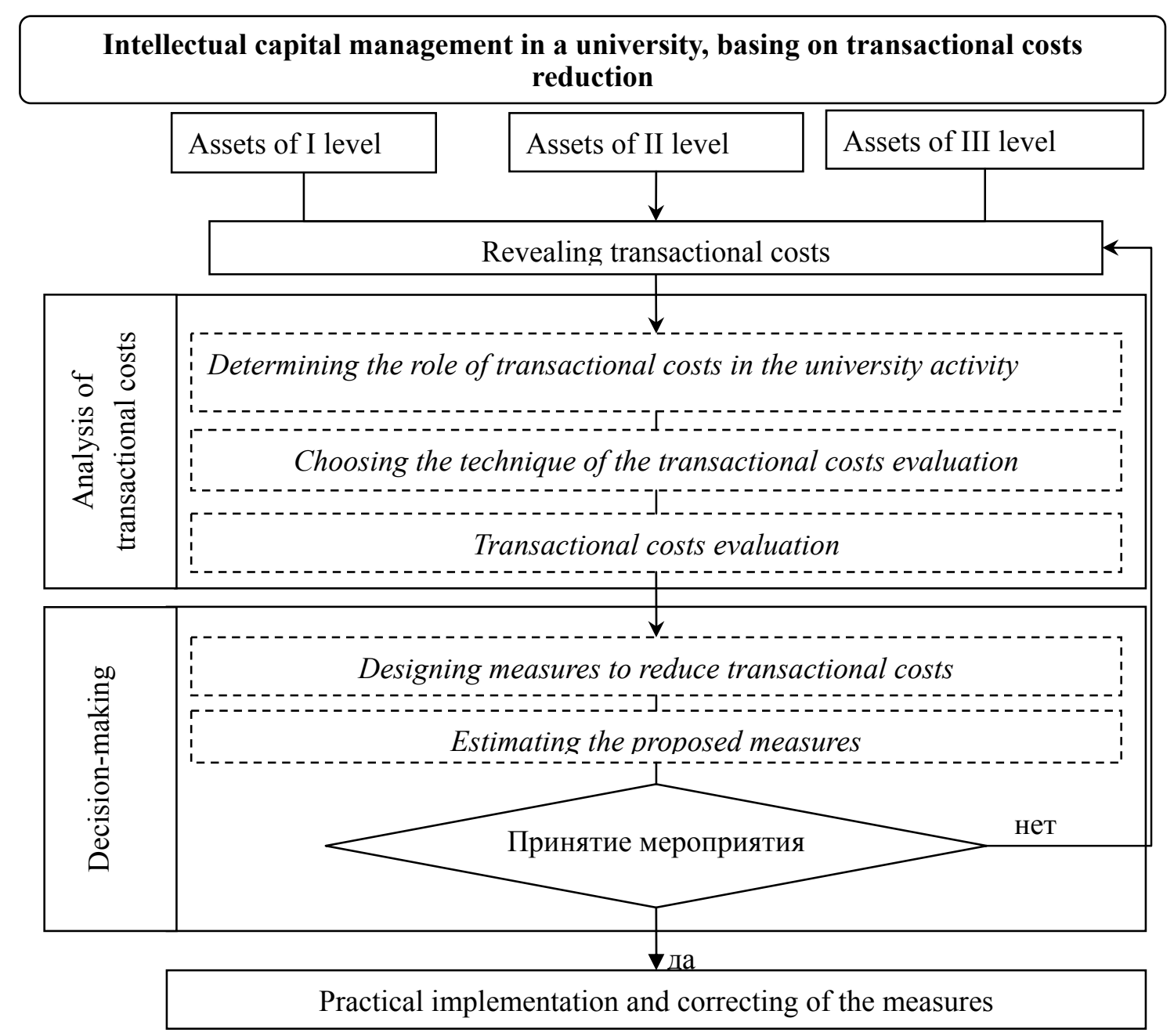

Figure 2. The model of intellectual capital management basing on transactional costs reduction

The competitiveness of organizations working in the field of educational services depends on effective intellectual capital management, it being the main component of the total capital of such organizations. At present a lot of works are devoted to the evaluation of the industrial enterprises' intellectual capital (Note 3). These assessment techniques do not adequately reflect the peculiarities of organizations functioning in the 
sphere of educational services. As the value of intellectual capital of institutions is affected by transaction costs (Brewer \& McEwan, 2010; Murphy \& Louis, 1999), the problem of increasing the intellectual capital value in the sphere of education by reducing transaction costs, can be considered topical, so the model of intellectual capital management of a university on the basis of transactional costs reduction is very meaningful (Figure 2).

The effective management of intellectual capital of a university requires to define the development objectives of the organization, which include: improving the quality of the educational process; increasing the target audience; strengthening the competitive positions in the labour market; increasing the sources of income and so on. To achieve these goals, one must determine which type of asset in the structure of intellectual capital has the greatest influence on the goal h, and what transaction costs are typical of this type of assets. It is necessary to analyze costs, as well as to develop measures for their reduction. After evaluation of the proposed measures, in case of a positive decision, it is possible to adjust measures when implementing the planned actions.

One of the goals of educational institutions under transition to the market economy is the increase of income. As universities are funded by revenues from physical and legal persons who pay for educational services, as well as from other activities, the main share of earnings come from paid educational activities.

He work views an example of a measure (the introduction of supervisors) aimed at reducing transaction costs of the III level assets.

To assess the effectiveness of measures aimed at intellectual capital increase, we used the discounted cash flow method, which allows to calculate the value of the object on the basis of the expected profit of investment. This paper examines the activities of a university, where the average training period is 5 years, after which the investment measures can be considered completed and the admission of students to the first course will be considered a new investment activity, which may have the different period of training, number of students, and, consequently, the number of supervisors. Therefore, when evaluating the intellectual capital of a university, the forecast period is assumed to be 5 years.

To determine the cash flow, we calculate (Note 4):

1) losses of the university associated with expulsion of full-time and correspondence students (Table 1):

- before the activities: $P_{i 0}=\bar{S} \cdot Q_{i} \cdot t$,

Where $P_{\mathrm{i} 0}$ is the sum not obtained by the university due to the expulsion of students; $S$ is average cost of studying at university per year; $Q_{i}$ is the number of expelled students; $t$ is the number of years which the students did not study after being expelled;

- after the activities: $P_{i 1}=P_{i 0} \cdot 0,89$,

as the supervisors institution allows to reduce losses by $11 \%$ on average,

where $P_{i 1}$ is the sum not obtained by the university due to the expulsion of students.

Table 1. Calculation of the is the sum not obtained by the university due to the expulsion of students before and after the activities

\begin{tabular}{ccccc}
\hline \multicolumn{5}{c}{ Losses in each studying year before the activities (thousand rubles) } \\
\hline $\mathbf{2 0 1 0} / \mathbf{1 1}$ & $\mathbf{2 0 1 1 / 1 2}$ & $\mathbf{2 0 1 2} / \mathbf{1 3}$ & $\mathbf{2 0 1 3} / \mathbf{1 4}$ & $\mathbf{2 0 1 4} / \mathbf{1 5}$ \\
773 & 510 & 450 & 443 & 68 \\
\hline $\mathbf{2 0 1 0} / \mathbf{1 1}$ & Losses in each studying year after the activities (thousand rubles) & $\mathbf{2 0 1 4 / \mathbf { 1 5 }}$ \\
688 & $\mathbf{2 0 1 1 / 1 2}$ & $\mathbf{2 0 1 2 / 1 3}$ & $\mathbf{2 0 1 3} / \mathbf{1 4}$ & 61 \\
\hline
\end{tabular}

2) the costs associated with the activities of the supervisors institution (table 2). Since the establishment of the supervisors institution the main costs are associated with salaries, investments can be calculated by the formula:

$$
I_{i}=\bar{Z} \cdot T_{i} \cdot K_{i},
$$

where $I_{i}$ is investment in the previous year; $\bar{Z}$ is the average cost of a normative hour of a supervisor; $T_{i}$ is the number of hour allocated for supervisor's activity; $K_{i}$ the number of supervisors. 
Table 2. Calculation of investments

\begin{tabular}{ccccc}
\hline \multicolumn{5}{c}{ Investments in each studying year (thousand rubles) } \\
\hline $\mathbf{2 0 1 0} / \mathbf{1 1}$ & $\mathbf{2 0 1 1 / 1 2}$ & $\mathbf{2 0 1 2 / 1 3}$ & $\mathbf{2 0 1 3 / 1 4}$ & $\mathbf{2 0 1 4 / \mathbf { 1 5 }}$ \\
\hline 30 & 24 & 18 & 12 & 4,5 \\
\hline
\end{tabular}

The cash flow will be calculated as the difference between the sum of losses associated with the students' expulsion before and after activities, taking investments into account (Table 3). For instance, in 2010/11 the cash flow will be equal to: $773-688-30=55$ thousand rubles.

Table 3. The influence of investment on the losses associated with the students' expulsion (thousand rubles)

\begin{tabular}{cccccc}
\hline Учебный год & $\mathbf{2 0 1 0} / \mathbf{1 1}$ & $\mathbf{2 0 1 1 / 1 2}$ & $\mathbf{2 0 1 2 / 1 3}$ & $\mathbf{2 0 1 3} / \mathbf{1 4}$ & $\mathbf{2 0 1 4 / 1 5}$ \\
\hline Losses in each studying year before the activities & 773 & 510 & 450 & 443 & 68 \\
Losses in each studying year after the activities & 688 & 454 & 401 & 394 & 61 \\
Investments & 30 & 24 & 18 & 12 & 5 \\
Cash flow & $\mathbf{5 5}$ & $\mathbf{3 2}$ & $\mathbf{3 2}$ & $\mathbf{3 7}$ & $\mathbf{3}$ \\
\hline
\end{tabular}

Using the method of discounted cash flows allows to calculate that the introduction of supervision institution helped the university to reduce the number of expelled students, therefore, the income from tuition fees will increase.

The measures for transactional costs reduction are associated with certain risks.

We interpret risk as the ability to obtain an unplanned result under the influence of both external and internal factors. There are various methods of risk identification, for example: statistical, analytical, expert. The most suitable method in this field are expert methods, because the lack of accumulated informational base does not allow to use other methods.

To identify and assess risk factors we formed an expert group of five people, which are directly linked to academic and extracurricular activities, admission of students and trainees, and carry out the financial service at university (Dean, Deputy Dean on educational work, Deputy Dean on Research work, manager of the Admission Commission, Deputy Chief Accountant).

To account for the risk associated with the introduction of supervision institution, we will reflect its level in the discount rate. The cumulative calculation method is the most suitable for these purposes as it allows to identify the various risk factors by an expertise.

The result is a total discount rate of $10,17 \%$.

The calculation of efficiency of introduction of the supervision institution is carried out according to the formula:

$$
N P V=N C F_{0}+\sum_{k=1}^{4} P V_{k}
$$

Table 3. Calculation of the discounted cash flow (thousand rubles)

\begin{tabular}{cccccc}
\hline Project period & $2010 / 2011$ & $2011 / 2012$ & $2012 / 2013$ & $2013 / 2014$ & $2014 / 2015$ \\
\hline Cash flow of zero period & 55 & 32 & 32 & 37 & 3 \\
The discounted cash flow (PV) & & 29 & 26 & 27 & 2 \\
The accumulated discounted cash flow & 55 & 84 & 110 & 137 & $\mathbf{1 3 9}$ \\
\hline
\end{tabular}

In this example the value of the discounted cash flow is positive (139 thousand rubles), consequently, the cash flows of the project in the studied period at the set discounting rate cover the investments and current costs.

Consequently, the supervision institution is a tool for transaction costs reduction of the III level assets. 


\section{References}

Bontis, N. (1998). Intellectual capital: an exploratory study that develops measures and models. Management decision, 36(2), 63-76. http://dx.doi.org/10.1108/00251749810204142

Bontis, N. (2001). Assessing knowledge assets: a review of the models used to measure intellectual capital. International journal of management reviews, 3(1), 41-60. http://dx.doi.org/10.1111/1468-2370.00053

Brewer, D. J., \& McEwan, P. J. (2010). Economics of education. Elsevier Science.

Cheng, M. Y., Lin, J. Y., Hsiao, T. Y., \& Lin, T. W. (2010). Invested resource, competitive intellectual capital, and corporate performance. Journal of intellectual capital, 11(4), 433-450. http://dx.doi.org/10.1108/ 14691931011085623

Costa, R. (2012). Assessing Intellectual Capital efficiency and productivity: an application to the Italian yacht manufacturing sector. Expert Systems with applications, 39(8), 7255-7261. http://dx.doi.org/10.1016/j. eswa.2012.01.099

Dezhina, I., \& Saltykov, B. (2005). The national innovation system in the making and the development of small business in Russia. Studies on Russian Economic Development, 16(2), 184-190.

Fazlagic, A. (2005). Measuring the intellectual capital of a university. Proc. of Trends in the Management of Human Resources in Higher Education, Poznan University of Economics, Poznan. Print.

Garcia-Parra, M., Simo, P., Sallan, J. M., \& Mundet, J. (2009). Intangible liabilities: beyond models of intellectual assets. Management decision, 47(5), 819-830. http://dx.doi.org/10.1108/00251740910960141

Gokhberg, L. (2004). Russia's National Innovation System and the" New Economy". Problems of Economic Transition, 46(9), 8-34.

Gokhberg, L., \& Kuznetsova, T. (2011). S\&T and Innovation in Russia: Key Challenges of the Post-Crisis Period. Journal of East-West Business, 17(2-3), 73-89. http://dx.doi.org/10.1080/10669868.2011.634769

Ketels, C., Lindqvist, G., \& Sölvell, Ö. (2006). Cluster initiatives in developing and transition economies. Center for Strategy and Competitiveness, Stockholm.

Madgett, P., Belanger, C. H., \& Mount, J. (2005). Clusters, innovation and tertiary education. Tertiary Education \& Management, 11(4), 337-354. http://dx.doi.org/10.1080/13583883.2005.9967155

Meek, V. L. (2000). Diversity and marketisation of higher education: incompatible concepts? Higher Education Policy, 13(1), 23-39. http://dx.doi.org/10.1016/S0952-8733(99)00030-6

Mertins, K., \& Will, M. (2007). A consistent assessment of intellectual capital in SMEs InCaS: intellectual capital statement-made in Europe. The Electronic Journal of Knowledge Management, 5(4), 427-436.

Murphy, J., \& Louis, K. S. (Eds.). (1999). Handbook of research on educational administration : a project of the American Educational Research Association (2nd ed.). San Francisco: Jossey-Bass Publishers.

Naidoo, R. (2003). Repositioning higher education as a global commodity: Opportunities and challenges for future sociology of education work. British Journal of Sociology of Education, 24(2), 249-259. http://dx.doi.org/10.1080/01425690301902

Nerdrum, L., \& Erikson, T. (2001). Intellectual capital: a human capital perspective. Journal of intellectual capital, 2(2), 127-135. http://dx.doi.org/10.1108/14691930110385919

Ramírez, Y., Tejada, Á., \& Baidez, A. (2013). Proposal of Indicators for Reporting on Intellectual Capital in Universities. Paper presented at the Proceedings of the 10th International Conference on Intellectual Capital, knowledge Management and Organisational Learning: ICICKM 2013.

Safiullin, L. N., Fatkhiev, A. M., \& Grigorian, K. A. (2014). The Triple Helix Model of Innovation. Mediterranean Journal of Social Sciences, 5(18), 203. http://dx.doi.org/10.1108/14691930110385919

Vagnoni, E., Guthrie, J., \& Steane, P. (2005). Recent developments in universities regarding intellectual capital and intellectual property. Health Policy and High-tech Industrial Development: Learning from Innovation in the Health Industry, Cheltenham, UK and Northampton, MA, USA: Edward Elgar, 103-124. http://dx.doi.org/10.4337/9781845424565.00016

Garifova, L. F., Kundakchyan, R. M., \& Pratchenko, O. V. (2014). Integral Estimate of Socio-Ecological-Economic Factors on the Quality of Life of Population of the Region. Mediterranean Journal of Social Sciences, 5(12), 117-121. http://dx.doi.org/10.5901/mjss.2014.v5n12p117 
Gibadullin, M. Z., Fazlieva, E. P., Nurieva, A. R., \& Grigoryeva, L. L. (2014). Territorial Aspects of Migration Processes in Russia. Mediterranean Journal of Social Sciences, 5(12), 93-96. http://dx.doi.org/10.5901/mjss.2014.v5n12p93

Nugumanova, L. F., Novenkova, A. Z., Abdulganiev, F. S., \& Toropova, N. V. (2014). The Role of Gender Factors in the Formation of Investment Attractiveness of the Territory. Mediterranean Journal of Social Sciences, 5(12), 97-102. http://dx.doi.org/10.5901/mjss.2014.v5n12p97

Nurieva, A. R., Gibadullin, M. Z., \& Fazlieva, E. P. (2014). Stability of Interregional Trade and Economic Relations as the Factor of Competitiveness of Territories. World Applied Sciences Journal, 29(4), 501-505.

\section{Notes}

Note 1. The review of models of intellectual capital evaluation (Bontis, 1998, 2001).

Note 2. See for instance (Ketels, Lindqvist, \& Sölvell, 2006; Madgett, Belanger, \& Mount, 2005; Safiullin, Fatkhiev, \& Grigorian, 2014)

Note 3. See for instance (Cheng, Lin, Hsiao, \& Lin, 2010; Costa, 2012; Garcia-Parra, Simo, Sallan, \& Mundet, 2009; Mertins \& Will, 2007)

Note 4 . The data corresponds to the internal documents.

\section{Copyrights}

Copyright for this article is retained by the author(s), with first publication rights granted to the journal.

This is an open-access article distributed under the terms and conditions of the Creative Commons Attribution license (http://creativecommons.org/licenses/by/3.0/). 